\title{
Pengaruh Tingkat Protein Ransum dan Lama Pencahayaan Terhadap Bobot Potong, Persentase Karkas dan Non Karkas Burung Puyuh Jantan
}

\section{Effect of Protein Level in Diet and Duration of Lighting on Slaughter Weight, Carcass and Non-Carcass Percentage of Male Quail}

\author{
U. Kulsum*, L. R. Muryani dan D. Sunarti \\ Fakultas Peternakan dan Pertanian, Universitas Diponegoro, Semarang, 50275 \\ ${ }^{*}$ E-mail: umikulsum3333@gmail.com
}

(Diterima: 21 Juli 2017; Disetujui: 5 September 2017)

\begin{abstract}
ABSTRAK
Penelitian ini bertujuan untuk mengetahui pengaruh tingkat protein ransum dan lama pencahayaan terhadap bobot potong, persentase karkas dan non karkas pada burung puyuh jantan. Penelitian ini menggunakan puyuh jantan umur 4 minggu berjumlah 275 ekor dengan rataan bobot badan $80 \pm 0,07$ gram $(\mathrm{CV}=9,00)$. Penelitian menggunakan rancangan acak kelompok pola petak terbagi dengan petak utama berupa penambahan cahaya C0 12 jam (18.00 - 06.00 WIB), C1 6 jam (18.00 - 00.00 WIB) dan C2 4 jam (18.00 - 22.00 WIB) sedangkan anak petaknya berupa tingkat protein dalam ransum P1 yaitu 18\%, P2 20\% dan P3 22\%. Tiap kelompok diulang sebanyak 3 kali dan setiap petak terdiri 10 ekor. Variabel yang diamati adalah bobot potong, persentase karkas dan persentase non karkas. Hasil penelitian mengindikasikan bahwa tingkat protein berpengaruh nyata $(\mathrm{P}<0,05)$ terhadap persentase non karkas tetapi tidak berpengaruh nyata $(\mathrm{P}>0,05)$ terhadap bobot potong dan persentase karkas sedangkan cahaya berpengaruh nyata $(\mathrm{P}<0,05)$ terhadap persentase karkas tetapi tidak berpengaruh nyata $(\mathrm{P}>0,05)$ terhadap bobot potong dan persentase non karkas.
\end{abstract}

Kata kunci: cahaya, tingkat protein, puyuh jantan, bobot potong, persentase karkas, persentase non karkas

\section{ABSTRACT}

The purpose of the research was to determine the effect of protein level in diet and duration of lighting on slaughter weight, carcass and non carcass percentage of male quail. The materials used were 275 male quails at 4 weeks old with mean body weight $80 \pm 0.07$ gram (CV=9.00). The research used group randomized split-plot design of main plot with additional lighting C0 12 hours (06.00 pm-06.00 am), C1 6 hours $(06.00 \mathrm{pm}-00.00 \mathrm{am})$ and C2 4 hours $(06.00 \mathrm{pm}-10.00 \mathrm{pm})$ whereas subplot with protein levels in diet P1 were (P1 18\%, P2 20\% and P3 22\%). Each group was repeated 3 times and each plot has 10 birds. The variables measured were slaughter weight, carcass and non carcass percentage of male quails. The result showed that protein level significantly effected $(P<0.05)$ non carcass percentage, but has no effect on slaughter weight and carcass percentage while lighting significantly effected $(P<0.05)$ carcass percentage but has no effect on slaughter weigh and non carcass percentage.

Keywords: lighting, level protei, male quail, slaughter weight, carcass percentage, non carcass percentage

\section{PENDAHULUAN}

Burung puyuh merupakan salah satu ternak unggas yang memiliki potensi besar untuk dikembangkan sebagai ternak penghasil protein hewani karena dalam pemeliharaannya tidak membutuhkan lahan yang lebih luas dan biaya pemeliharaannya tidak terlalu besar (Mahfudz et al., 2009). Puyuh jantan biasanya langsung digunakan sebagai pakan lele dan burung pemeliharaan. Padahal, daging puyuh merupakan daging yang disukai masyarakat dan memiliki kandungan nutrisi yang baik untuk tubuh manusia. Oleh karena, itu burung puyuh jantan dapat dimanfaatkan sebagai penghasil daging.

Untuk mendapatkan hasil dari 
Tabel 1. Bahan pakan yang digunakan dalam ransum.

\begin{tabular}{lrrr}
\hline \multirow{2}{*}{ Bahan Pakan } & \multicolumn{3}{c}{ Perlakuan Level Protein } \\
\cline { 2 - 4 } & P1 $(18 \%)$ & P2 $(20 \%)$ & P3 (22\%) \\
\hline Jagung (kg) & 50,50 & 51,50 & 49,00 \\
Bekatul (kg) & 25,00 & 20,00 & 19,00 \\
Bungkil Kedelai (kg) & 11,75 & 15,00 & 16,00 \\
Tepung Ikan (kg) & 10,00 & 11,00 & 14,00 \\
CaCo $_{3}(\mathrm{~kg})$ & 1,75 & 1,50 & 1,00 \\
Premix (kg) & 1,00 & 1,00 & 1,00 \\
\hline Jumlah & 100,00 & 100,00 & 100,00 \\
\hline Energi Metabolis (kkal/kg) & 3029,44 & 3011,53 & 2982,65 \\
Protein kasar (\%) & 18,00 & 20,02 & 22,09 \\
Lemak kasar (\%) & 6,59 & 6,16 & 6,37 \\
Serat kasar (\%) & 2,89 & 2,86 & 2,82 \\
Ca (\%) & 1,72 & 1,72 & 1,74 \\
P (\%) & 0,51 & 0,50 & 0,51 \\
\hline
\end{tabular}

Pertumbuhan puyuh jantan yang baik, harus diikuti dengan manajemen pemeliharaan yang baik, baik dari segi kebutuhan pakan, sistem pemeliharaan, kondisi lingkungan dan sistem pencahayaan dalam kandang. Kebutuhan ransum sangat berkaitan dengan program lama pencahayaan dalam kandang karena penerangan merupakan salah satu faktor yang mempengaruhi konsumsi protein dalam ransum. Pada kondisi terang, puyuh dapat melihat pakan sehingga mudah untuk mengkonsumsi sedangkan pada periode gelap aktivitas fisik ternak rendah dan pengeluaran energi untuk aktivitas berkurang sehingga memberi kesempatan puyuh untuk beristirahat.

Pemberian program lama pencahayaan dan level protein yang berbeda dilakukan untuk meningkatkan produktivitas karena pemberian cahaya yang tepat dapat mengurangi tingkat stres ternak dan meningkatkan jumlah pakan yang dikonsumsi. Jumlah pakan yang masuk kedalam tubuh (feed intake) serta pemberian protein dalam ransum yang sesuai dengan kebutuhannya akan mendukung terhadap produksi karkas yang dihasilkan. Protein merupakan bagian terbesar yang dibutuhkan puyuh untuk penyusunan jaringan otot atau karkas.

\section{METODE}

Materi yang digunakan dalam penelitian adalah 275 burung DOQ (Day Old Quail) puyuh petelur jantan (Cortunix cortunix japonica) umur 4 minggu dengan bobot badan $80 \pm 0,07$ gram, $(\mathrm{CV}=9,00)$. Kandang yang digunakan sebanyak 27 petak yang dibagi menjadi 3 kelompok dan setiap petak diisi 10 ekor burung puyuh. Setiap petak kandang dilengkapi dengan sebuah tempat pakan dan minum masing-masing berjumlah 27 buah serta sebuah lampu penerangan. Ransum disusun dengan komponen seperti pada Tabel 1. Alat lain yang disediakan berupa higrometer (Pengukur kelembaban kandang), termometer (mengukur suhu kandang), timbangan digital (alat penimbang pakan, ternak dan karkas), kipas angin (meminimalisir hawa panas pada siang hari), tirai plastik (melindungi angin dan hujan), tirai terpal (menghalangi cahaya yang dapat masuk dari luar), dan kertas kardus (penutup kandang agar kandang yang masih memiliki pencahayaan tidak mengganggu kandang lain yang lampunya sudah di padamkan).

Metode penelitian dilakukan meliputi tiga tahapan yaitu tahap persiapan, tahap pelaksanaan penelitian dan tahap pengambilan 
Tabel 2. Rataan bobot potong puyuh jantan.

\begin{tabular}{ccccc}
\hline Faktor C & \multicolumn{3}{c}{ Faktor P (Level Protein) } & \multirow{2}{*}{ Rataan } \\
\cline { 2 - 4 } (Lama Cahaya ) & P1 & P2 & P3 & 81,33 \\
C0 & 81,50 & 84,33 & 78,17 & 81,94 \\
C1 & 81,83 & 80,33 & 83,67 & 80,72 \\
C2 & 82,17 & 81,17 & 78,83 & \\
\hline Rataan & 81,83 & 81,94 & 80,22 & \\
\hline
\end{tabular}

Keterangan : bobot potong tidak berpengaruh nyata pada cahaya $(\mathrm{P}>0,05)$ dan protein $(\mathrm{P}>0,05)$

data. Rancangan percobaan yang digunakan adalah Rancangan Acak Kelompok (RAK) dengan pola Petak Terbagi (Split Plot) $3 \times 3$ dengan 3 ulangan. Terdiri dari cahaya sebagai main plot atau petak utama berupa $\mathrm{C} 0, \mathrm{C} 1$ dan $\mathrm{C} 2$ kemudian anak petaknya berupa level protein berupa P1 (18\%), P2 (20\%), dan P3 (22\%). Pengambilan data diperoleh dengan cara memuasakan puyuh sebelum dipotong, setelah dipotong dilakukan penimbangan dan dicatat sesuai data yang dibutuhkan. Parameter yang diambil yaitu:

\section{Bobot potong}

Puyuh jantan diambil 2 ekor/unit kemudian menimbang puyuh sesudah disembelih.

\section{Persentase karkas}

Puyuh jantan diambil 2 ekor/unit kemudian menimbang bobot karkas dan dihitung persentasenya:

$$
=\frac{\text { Bobot karkas }}{\text { Bobot hidup }} \times 100 \%
$$

3. Persentase non karkas

Puyuh jantan diambil 2 ekor/unit kemudian menimbang bobot non karkas dan dihitung persentasenya.

$$
=\frac{\text { Bobot non karkas }}{\text { Bobot hidup }} \times 100 \%
$$

\section{HASIL DAN PEMBAHASAN}

\section{Pengaruh Perlakuan Terhadap Bobot Potong Puyuh}

Berdasarkan analisis ragam, tidak terdapat interaksi yang nyata $(\mathrm{P}>0,05)$ antara tingkat protein dan lama pencahayaan terhadap bobot potong. Demikian juga dengan perlakuan tingkat protein dan lama pencahayaan, menunjukkan tidak berpengaruh nyata $(\mathrm{p}>0,05)$ terhadap bobot potong.

Tidak terdapat Interaksi yang nyata $(\mathrm{P}>0,05)$ lama pencahayaan dan tingkat protein terhadap bobot potong. disebabkan karena pada saat mendapatkan pencahayaan (terang) puyuh dapat mengkonsumsi ransum yang tidak dikonsumsinya pada saat dipadamkan (gelap). Hubungan antara cahaya dan protein sesuai pendapat Pow dan Cook (1997), triptopan merupakan asam amino netral besar yang digunakan dalam biosintesis zat neuroactive seperti seratonin dan melatonin. Hormon seratonin dan melatonin berkaitan dengan konsumsi pakan, tekanan darah, suhu tubuh dan pertumbuhan. Sainio et al. (1996) bahwa kandungan triptopan dalam asam amino protein berfungsi sebagai prekursor, seratonin, melatonin, tryptamin dan koenzim (NAD dan NADP) yang mengatur efek neurobehavirol seperti nafsu makan, istirahat, implusif dan perilaku seksual.

Tabel 2 menunjukkan tingkat protein ransum tidak mempengaruhi $(\mathrm{P}>0,05)$ bobot potong puyuh jantan. Hal ini disebabkan karena pada dasarnya puyuh mengkonsumsi protein sesuai dengan kebutuhan nutrisi tubuhnya sehingga kandungan protein sebesar $18 \%, 20 \%, 22 \%$ dalam ransum tidak mempengaruhi terhadap bobot potong. Fillawati (2008) menyatakan kandungan energi, protein dan serat kasar yang terdapat dalam ransum merupakan salah satu faktor yang dapat mempengaruhi konsumsi ransum 
Tabel 3. Rataan persentase karkas.

\begin{tabular}{ccccc}
\hline Faktor C & \multicolumn{3}{c}{ Faktor P (Level Protein) } & \multirow{2}{*}{ Rataan } \\
\cline { 2 - 4 } (Lama Cahaya) & P1 & P2 & P3 & \\
\hline C0 & 60,48 & 65,71 & 63,91 & $63,37^{\mathrm{c}}$ \\
C1 & 63,39 & 63,85 & 63,39 & $63,54^{\mathrm{b}}$ \\
C2 & 64,36 & 64,76 & 63,55 & $64,22^{\mathrm{a}}$ \\
\hline Rataan & 62,74 & 64,78 & 63,61 & \\
\hline
\end{tabular}

Keterangan: Persentase tidak berpengaruh nyata pada protein $(\mathrm{P}>0,05)$ dan berpengaruh sangat nyata pada cahaya $(\mathrm{P}<0,05)$.

sehingga akan berpengaruh pada bobot hidup dan bobot potong yang dihasilkan.

Lama pencahayaan tidak berpengaruh nyata $(\mathrm{P}>0,05)$ terhadap bobot potong. Hal ini disebabkan karena puyuh dapat melakukan kompensasi konsumsi ransumnya. Pencahayaan akan berpengaruh langsung terhadap mata. Cahaya akan merangsang hipotalamus sebagai pusat dari sistem hormonal untuk memerintahkan hipofisa pituitari anterior untuk mengeluarkan hormon TSH (thyroid stimulating hormone) dan hormon somatatropin, kedua hormon ini berperan dalam pertumbuhan. Coban et al. (2009) menyatakan bahwa pencahayaan yang diberikan secara terus menerus dapat memberikan hasil bobot akhir yang tinggi dan berpengaruh terhadap bobot potong untuk burung puyuh.

\section{Pengaruh perlakuan terhadap persentase karkas puyuh jantan}

Berdasarkan hasil analisis ragam tidak terdapat interaksi yang nyata $(\mathrm{P}>0,05)$ antara lama pencahayaan dan tingkat protein terhadap persentase karkas, demikian juga dengan perlakuan tingkat protein menunjukkan tidak berpengaruh nyata $(\mathrm{P}>0,05)$, namun perlakuan lama pencahayaan berpengaruh nyata $(\mathrm{P}<0,01)$ terhadap persentase karkas puyuh jantan.

Interaksi antara pemberian tingkat protein dan lama pencahayaan tidak berpengaruh nyata $(\mathrm{P}>0,05)$ terhadap persentase karkas. disebabkan karena tingkat protein ransum tidak berkaitan langsung dengan pencahayaan dalam mempengaruhi persentase karkas. Sainsburry (1999) bahwa hormon tiroid akan berperan dalam deposisi protein pada saat ternak memperoleh periode gelap dan disaat terang hormon tiroksin akan bekerja mengatur metabolisme, sinergi kerja hormon terhadap pencahayaan akan mempengaruhi bobot badan dan persentase karkas.

Pemberian tingkat protein tidak berpengaruh nyata $(\mathrm{P}>0,05)$ terhadap persentase karkas. Tidak adanya pengaruh pada perlakuan ini karena protein dalam ransum sudah memenuhi kebutuhan nutrisinya, namun tidak berpengaruh terhadap bobot potong sehingga mempengaruhi persentase karkas yang dihasilkan. menurut pendapat Dewanti et al. (2013) bahwa persentase karkas dipengaruhi oleh bobot potong, persentase karkas berawal dari laju pertumbuhan yang ditunjukkan dengan adanya pertambahan bobot badan akan mempengaruhi bobot potong yang dihasilkan. bobot potong akan berpengaruh pada persentase karkas yang dihasilkan.

Persentase karkas dipengaruhi juga oleh umur pemotongan, dimana puyuh yang dipotong pada umur tua akan mengalami peningkatan berat kepala dan organ dalam, sehingga persentase karkas mengalami penurunan. Narin et al. (2014) bahwa standar pemotongan puyuh untuk menghasilkan karkas yang maksimal yaitu umur 6 minggu dan maksimum memiliki bobot badan $80 \mathrm{~g}$.

Lama pencahayaan memberikan pengaruh nyata $(\mathrm{P}<0,05)$ terhadap persentase karkas. Rataan persentase karkas tertinggi terdapat pada perlakuan $\mathrm{C} 2$ dengan rataan $64,22 \%$ dan yang paling rendah pada 
Tabel 4. Rataan persentase non karkas.

\begin{tabular}{ccccc}
\hline Faktor C & \multicolumn{3}{c}{ Faktor P (Level Protein) } & \multirow{2}{*}{ Rataan } \\
\cline { 2 - 4 } (Lama Cahaya) & P1 & P2 & P3 & \\
\hline C0 & 31,35 & 28,95 & 31,49 & 30,59 \\
C1 & 24,55 & 26,59 & 26,52 & 25,89 \\
C2 & 24,71 & 26,74 & 28,15 & 26,53 \\
\hline Rataan & $26,87^{\mathrm{c}}$ & $27,42^{\mathrm{b}}$ & $28,72^{\mathrm{a}}$ & \\
\hline
\end{tabular}

Keterangan: Persentase tidak berpengaruh nyata pada cahaya $(\mathrm{P}>0,05)$ dan berpengaruh nyata pada protein $(\mathrm{P}<0,05)$.

perlakuan C0 dengan rataan $63,37 \%$. Dari hasil penelitian ini terlihat semakin sedikit cahaya yang diberikan menyebabkan rataan persentase karkas puyuh besar. Hal ini disebabkan karena dengan adanya cahaya puyuh dapat mengkonsumsi ransum dengan baik dan ketika lampu gelap puyuh lebih memilih untuk istirahat dari aktivitasnya sehingga puyuh tidak mengalami stres. Hal ini sesuai dengan pendapat Lewis dan Gous (2007), pembatasan cahaya bertujuan memberikan kesempatan bagi ternak untuk beristirahat dari makan dan mendukung proses pencernaan didalam tubuh sehingga pencernaan akan berlangsung secara optimal dan mengurangi pengeluaran energi.

\section{Pengaruh Perlakuan Terhadap Persentase Non Karkas Burung Puyuh Jantan}

Berdasarkan hasil analisis diperoleh rataan persentase non karkas pada Tabel 4 . Berdasarkan analisis hasil keragaman tidak terdapat interaksi yang nyata $(\mathrm{P}>0,05)$ antara lama pencahayaan dan tingkat protein terhadap persentase non karkas, demikian juga dengan perlakuan lama pencahayaan menunjukkan pengaruh tidak nyata $(\mathrm{P}>0,05)$ sedangkan tingkat protein menunjukkan pengaruh nyata $(\mathrm{P}<0,05)$ terhadap persentase non karkas.

Interaksi antara pemberian tingkat protein dan lama pencahayaan tidak berpengaruh nyata $(\mathrm{P}>0,05)$ terhadap persentase non karkas. hal ini dapat disebabkan karena puyuh pada peneitian ini dipotong pada umur 8 minggu, tergolong umur pemotongan yang sudah tua. Narinc et al. (2014) menyatakan bahwa puyuh yang umurnya tua cenderung memiliki organ dalam, kaki, kepala dan lemak abdominal lebih besar sehingga meningkatkan bobot non karkas dan menurunkan produksi karkas.

Pemberian tingkat protein berpengaruh nyata $(\mathrm{P}<0,05)$ terhadap persentase non karkas. rataan persentase non karkas tertinggi yaitu $\mathrm{P} 3$ sebesar 28,72\% dan terendah P1 sebesar 26,87 $\%$. Dari hasil penelitian ini, semakin tinggi protein dalam ransum menyebabkan rataan persentase non karkas puyuh semakin tinggi. Peningkatan kandungan protein pada ransum akan meningkatkan konsumsi ransumnya. Unggas mengkonsumsi ransum bertujuan untuk memenuhi kebutuhan energinya, dan protein dalam ransum dapat dicerna karena adanya energi. Protein ransum tersebut apabila diubah menjadi protein tubuh membutuhkan energi untuk metabolisme dalam saluran pencernaan maupun metabolisme sel. Menurut pendapat Siri et al. (1992), semakin banyak ransum yang dikonsumsi, semakin aktif kerja usus untuk mencerna pakan sehingga dapat merangsang pertumbuhan organ pencernaan yang tinggi.

Lama pencahayaan tidak berpengaruh nyata $(\mathrm{P}>0,05)$ terhadap non karkas. Rataan persentase non karkas berkisar 25,89 $30,59 \%$. Hal ini disebabkan karena pada waktu terang kesempatan untuk mengkonsumsi pakan meningkat sehingga puyuh leluasa mengkonsumsi pakan untuk kebutuhan pokok maupun pertumbuhan organnya. Kliger et al. (2000) bahwa program pencahayaan secara berselang akan merangsang hormon-hormon untuk bekerja sesuai dengan fungsinya. 


\section{KESIMPULAN}

Berdasarkan hasil penelitian, tingkat protein mampu menaikkan persentase non karkas puyuh jantan sedangkan cahaya mampu menaikkan persentase karkas burung puyuh jantan umur 8 minggu.

\section{SARAN}

Sebagai saran penelitian lebih lanjut berkaitan warna lampu, intensitas cahaya, daya watt dan tingkat protein yang diperlukan.

\section{DAFTAR PUSTAKA}

Coban, O., E. Lacin, N. Sabuncuoglu dan Z. Ozudogru. 2009. Effect of selfphotoperiod on live weight, carcass and growth traits in quails (Coturnix coturnix japonica). J Anim Sci. 22 (3): 410-415.

Dewanti, R., M. Irham dan Sudiyono. 2013. Pengaruh penggunaan enceng gondok (Eichornia crassipes) terfermentasi dalam ransum terhadap persentase karkas, non-karkas, dan lemak abdominal itik lokal jantan Umur Delapan Minggu. Buletin Peternakan Vol. 37(1): 19-25, Februari 2013. hlm. 19-25

Fillawati. 2008. Pengaruh penggunaan bungkil kelapa yang difermentasikan dengan tape dalam ransum terhadap bobot karkas broiler. J. Ilmiah IlmuIlmu Peternakan. 11(4): 93-99.

Kliger, C. A., A. E. Gehad, R. M. Hulet, W. B. Roush, H. S. Lillehoj and M. M. Mashaly. 2000. Effects of photoperiod dan melatonin on lymphocyte activities in male broiler chickens. J. Poultry. Sci. 79: $18-25$.
Lewis, P. D. and R. M. Gous. 2007. Broilers perform better on short or step up photoperiods. South Afr. J. Anim. Sci. 37 (2): 90-96.

Mahfudz, L. D., T. A. Sarjana dan W. Sarengat. 2009. Efisiensi Penggunaan Protein Ransum yang Mengandung Limbah Distilasi Minuman Beralkohol (LDMB) oleh Burung Puyuh (Coturnix coturnix japonica) Jantan. Dalam: Prosiding Seminar Nasional Kebangkitan Peternakan. Fakultas Peternakan. Universitas Diponegoro. hal. $887-894$.

Narinc, D., E. Karaman dan T. Aksoy. 2014. Effects of slaughter age and mass selection on slaughter and carcass characteristics in 2 lines of japanese quil. J Poultry Science. 93: 762-760.

Pow, D. V. and D. K. Cook. 1997. Tryptophan is present in glial cells and photoreceptors in the chicken retina. Neuroreport. 6; 8(7): 1767-70.

Sainsbury D. 1999. Poultry Health dan Management; Chicken, Turkey, Ducks, Geese dan Quail. 4 Th. Ed. University of Cambride. 195 Service of Mississippi State University, cooperating with U.S. Department of Agriculture. Availableat: http://poultryone. com/ articles/feedingquail.html. Accession date: 29th September, 2011.

Sainio, E. L., K. Pulkki and S. N. Young. 1996. L-Tryptophan: Biochemical, nutritional and pharmacological aspects. Amino Acids 10: 21-47.

Siri, S., S. Tabioka dan I. Tasaki. 1992. Effect of dietary fiber on growth performance, development of intestinal organs, and energy utilization, and lipid content of growing chicks. J. Poult. Sci. 20: 106113. 